\title{
Title of review
}

\section{Being Social in Organizational Studies: The Early Works of Stewart Clegg}

\section{Books reviewed}

Clegg, S. R., Boreham P. and Dow G. (2013) Class, Politics and the Economy. Oxon: Routledge Revivals. ISBN 0415715474. 462 pp.

Clegg, S. R., Boreham P. and Dow G. (eds) (2013) The State, Class and the Recession.

Oxon: Routledge Revivals. ISBN 1134716400. 346 pp.

Clegg, S. R. and Dunkerley D. (2013) Organization, Class and Control, London and Boston. Oxon: Routledge Library Editions. ISBN 0415823080. 632 pp.

Clegg, S. R. (2013) The Theory of Power and Organization. Oxon: Routledge Library Editions. ISBN 0415822505. $192 \mathrm{pp}$

Clegg, S. R. and Dunkerley D. (eds) (2013) Critical Issues in Organization. Oxon:

Routledge Library Editions. ISBN 0415822939. 120 pp.

Clegg, S. R. (2013) Power, Rule and Domination: A Critical and Empirical

Understanding of Power in Sociological Theory and Organizational Life. Oxon:

Routledge Library Editions. ISBN 0415822491. 224 pp.

\section{Authors of review}

Ace V. Simpson, UTS Business School, University of Technology, Sydney Marco Berti, UTS Business School, University of Technology, Sydney

\section{Email}

Ace Volkmann Simpson : Ace.Simpson@uts.edu.au

Marco Berti: Marco.Berti@uts.edu.au

\section{Postal adrress}


UTS Faculty of Business, Management Discipline Group PO Box 123 Broadway

Sydney, New South Wales 2007 Australia

\section{Note on contributors}

Ace V. Simpson is a lecturer in management within the UTS Business School at the University of Technology, Sydney. He is also a member of the Centre for Management and Organization Studies (CMOS), one of Australia's most highly ranked management research centers. His research brings a critical social theory contribution to positive organizational scholarship.

Marco Berti is a management consultant with a 20 years international experience and an adjunct lecturer in management within the UTS Business School at the University of Technology, Sydney. He is currently completing its $\mathrm{PhD}$ (an ethnographic study on the production of academic identities and practices).

\section{Introduction}

Routledge Revivals, an initiative that aims to reissue out of print works by distinguished academics, has republished six early publications (co-)authored or edited over an 11-year period between 1975 and 1986 by Stewart Clegg. These are works by Clegg as an early career researcher, not yet established in either sociology or management but hovering in between the two disciplines.

Clegg's (2005) 'Vita Contemplative' indicates that he wrote the first of these books as a lonely sociologist in a Management Centre. The second was also produced therein but in the context of involvement in the nascent stages of the European Group for Organization Studies (EGOS), whose founding meeting was held in 1974. The third was written in the setting of an avant garde School of Humanities at Griffith University, where Clegg was also a lone sociologist amongst a vibrant crew of motley talents but where he teamed up with Geoff Dow, a political economist and his friend Paul Boreham (from the University of Queensland), an industrial sociologist. The other books were published when Clegg was Head of the Sociology Department at the University of New 
England. Thus, the collaborative resources engaged with were far from Management. There was no Business School within Queensland's universities at the time of his early appointment.

These books laid the foundations for his subsequent work by emphasising the social, particularly power relations, within management and organizational studies leading to his becoming the acclaimed organization and management scholar of today. Broadly, the six early books by Clegg concern both organizations and sociology, with differing emphases in each volume. The following is a chronological review of these early texts, concluding with some overall observations on the value they might contribute to contemporary scholarship.

\section{Power, rule and domination: $A$ critical and empirical understanding of power in sociological theory and organizational life}

Initially written as Clegg's (2013 [1975]) doctoral thesis, Power, rule and domination is driven by two sources of dissatisfaction for the young researcher. He was unhappy with the copious and contradictory depictions of power within the sociological literature that were incapable of providing an agreed upon formal definition of something that, in lay terms, is a common-sense phenomenon. He was also frustrated that most of these conceptualisations were unable to account for the empirical field observations Clegg was making at a building site in northern England.

Clegg's analysis focuses on a few selected conversations recorded during his ethnographic data gathering. What he describes is the potent effect of underlying structures that align and stratify the thinking and behaviours of organisational members. Empowered relations are governed by taken for granted assumptions, set arrangements of ideas, objects and bodies, that enable specific outcomes and not others, making possible only certain interpretations and exchanges. With the sole exception of Gramsci's (1971) ideas, which had only recently been translated and published in English at the time, Clegg's description of structural power went beyond the forms of policing, compulsion and manipulation described by the literature up until that time.

Clegg was clearly on the verge of theorizing (at the same time or just before?) the very notion that soon would produce a Copernican revolution in the understanding of 
power: Foucauldian discourse. The absence of such an idea in the conceptual toolbox available to him, however, saw him have recourse to more tortuous labels such as "models of rationality" (after Weber) or "forms of life" (after Wittgenstein).

The impact of interpretation on the understanding of power is another topic introduced in Clegg's seminal work. He describes how language games mould and define understanding of social phenomena in general and of power in particular. Inspired by Garfinkel (1967), he suggests that descriptions of power have an indexical nature. In other words they are bound to context and observational setting: therefore different "theoretical grammars" produce entirely different accounts of the same phenomenon. Such reasoning raises an interesting paradox: how can we be sure we are referring to the same phenomenon if we doubt the "objective" nature of the expression? Unfortunately, he does not fully explore this trail of inquiry and it tends to assume a minor role in his next publications. The "rediscovery" of this intuition seems to re-emerge in his later intellectual inquiry: his most recent works aim at overcoming the attribution of positive and negative values to power exercise, directing his analytical focus to the "normalcy" of apparently extreme evil forms of power exercise (Clegg, Cunha, and Rego 2012b) and the oppressive implications of "positive" expressions of power (Clegg, Cunha, and Rego 2012a; Simpson, Clegg, and Freeder 2013). While this might appear a sideways approach, it is probably the only way to escape the vertigo of infinite regression which looms over those attempting to tackle the relationship between sense-making and an analysis of power: if knowledge and power are mutually constitutive, then our knowledge of power should produce the capacity to discern and debate power's effects.

In sum, this early work already contains all the elements that mark the remarkable intellectual career of Stewart Clegg. In it he demonstrates a love of sophisticated thinking and an acute philosophical and sociological gaze: one that shatters the illusion of normalcy and self-evidence in organisational life, exposing the political and ethical problems that agitate any social setting.

\section{Critical Issues in Organizations}

Edited by Clegg and Dunkerley (2013 [1977]), Critical Issues is a pioneering text that laid the foundations for what has become established as the field of Critical Management 
Studies (Fournier and Grey 2000). Critical Issues is critical both in the sense of critique and in the sense of bringing attention to issues that are crucial or essential for organizational theory, yet had not until this point been considered. The editors (and their contributors) critique existing American organization theory for its lack of reflexivity, historicity along with a subservience to administration ideologies, demonstrated by ignoring Marxian thought and misinterpreting Weber to suit managerial agendas. The editors charge that, "The interests of management and the interests of organization theory have all too often been in harmony" (p. 2). A call is made for righting this wrong by "widening the scope of organization theory in order to account for social, political, economic, historical influences within society in their impact in the organization" (pp. 34) and "infusing insights and ambitions from economic and political sociology" (p. 87). Along these lines the editors saw hope in the emergence in 1975 of a "distinctively European tradition" in the European Group for Organizational Studies (EGOS), a group committed to reawakening, renewing and discussing critical issues that had been for so long "condemned to silence" (p. 2).

Supporting their rhetoric with practice, the editors and contributors provide five chapters on a broad spectrum of social issues, which had "not been found in the indexes of most texts of organizations" (p. 2) including gender, capitalism, power, ideology and the influence of macro institutional forces such as the role of the state and the political economic context. In the first chapter Wolff discusses sexism in organizations arguing that when compared with men regarding conditions of employment in UK organizations, women have been disadvantaged and that such sexism is not accounted for in traditional organizational theory. She thereby indicates the need for a broadened theoretical approach that accounts for social influences upon and within organizations.

Clegg's chapter criticizes theoretical formulations of power that take decision making as the indicator of organizational authority. Prior consensus that decisions conform to the interests of the dominant power structure mean that actual power need not be exercised. Further, constant capacity to legitimize or veto actions means that for the most part managerial power may remain silent, as worker participation and codetermination act as tools of employee discipline, compliance and cooperation. 
Karpik discusses capitalist development, providing a broad historical account of enterprise as a social construct that has emerged to its current form in producing material life as technological capitalism - as opposed to industrial or merchant capitalism. Karpik seeks to reveal the various institutional categories of control that cut across different types of organizations as in the domination of technological capitalism. In doing so he prefigures the concern with institutional logics.

McCullough and Shannon describe processes of interactions between transnational organizations and nation-states, with illustrative references to Northern Ireland. Their approach to theorizing is to position historical events within the environment, so that these are framed as concrete units of analysis that manifest "internal contradictions of the world capitalist system" (p. 82).

Wassenberg constructs a theoretical framework involving three dynamic macro dimensions of analysis: the inter-organizational dimension of "bounded inter dependence," the cultural dimension of "bounded rationality", and the political dimension of "bounded legitimacy". The framework facilitates consideration of the transactions and interactions dynamically shape inter-organizational relations.

Theoretically, these chapters are grounded in the perspectives of Marxism and phenomenology but also show the beginnings of what has come to be known as institutional theory. The chapters are sometimes difficult to read for no less reason than that they are set in typewriter typeset. Nonetheless, history has borne witness to the ways in which these essays broke new ground in examining issues previously ignored or sidelined in organization theory.. They thereby delivered on the book's objective of laying the foundations for a more reflexive, dialectic and critical approach to organizational studies.

\section{The theory of power and organization}

Clegg's (2013 [1979]) The theory of power and organization is another decisive reference in the founding of a more critical, sociological approach to management and organization studies. Instead of following his commission to provide an analysis of "recent European work on the theory of power, with particular reference to the analysis of organization" (p.1), Clegg sets about demonstrating the problematic nature of power 
by rejecting any objectification of the phenomenon. He introduces the work as an antidote to both 'logo-centrism' (the reification of phenomena through the use of an arbitrary set of definitions) and 'socio-centrism' (assuming conventional, common knowledge as point of reference). Most contemporary political scientists and organizational theorists were embracing a Hobbesian individualist view of power focused on agent-driven actions aimed at controlling other agents' behaviors. Clegg rejected this approach as inevitably superficial and unproblematic. In his view it applied primarily to the "one-dimensional" view of power as proposed by Simon (1952) and Dahl (1957) who described power as the capacity to intentionally cause behavior. Even the 'radical' conceptions pointing to the existence of a further layer of power based on the control of the discussion agenda (Bachrach and Baratz 1962), or on the manipulation of interests and desires (Lukes 1974) were unsatisfactory to Clegg. Despite their "revolutionary" claims, these theorizations were operating within the same language-game, based on a causal individualist view.

Clegg dismisses such agency-based conceptions of power as ineffectual, breaking with this paradigm through a reconceptualization of power as the expression of structural forces. While Giddens (1976) had tried to synthesize power and structure, according to Clegg his analysis suffered from a subjective voluntaristic bias. Instead it is Gramsci's concept of hegemony that provides the author with an alternate grammar of power. Hegemony is the bundle of ideal, cultural, material and economic factors, embedded in and reproduced by practices supporting the domination of a ruling class that are "not necessarily tied to class" (p.89). Such practices constitute the structural rationality that maintains a mode of production (e.g. capitalism). Individual power relationships thereby become only epiphenomena, since "the power that employees have is a capacity which is only possible within the framework of hegemonic domination to which they would first have to submit" (p.148): examples of this form of hegemonic control are given by technical rules, such as those prescribed by Taylorism, or by social-regulative rules of peer co-operation as described by Mayo. Power becomes a combination of force and consent and is normalized in the taken for granted structures and practices of social life. Consequently the Leviathan is not a benign monster, an anthropomorphic creature gifted 
with human intellect and volition, but a lovecraftian horror, an inhumane entity that can mercilessly crush the lives of insignificant individuals.

The "sedimented principles of selection rules" which operate as structures of domination are human-made but no one person controls them, even if cunning individuals can exploit them to promote their own interests. The contemporary phenomena of global financial crisis and of global warming constitute empirical demonstration of this idea.

The most pervasive form of power is therefore exercised through the adoption of unquestioned routines and discourses rather than through willing impositions. Resistance is not won with force nor circumvented through manipulation but rather dissolved by means of a process of rationalisation: structural, hegemonic power express all its muscle when opposition is perceived as eccentricity, weirdness or sheer mental insanity.

Reading this book more than three decades after its publication one element stands out because of its absence: while the argument is strongly post-modern, the work of Foucault is only cited parenthetically. Clearly Clegg had not yet included Discipline and Punish (Foucault 1977) in his vast readings. Another limitation is the failure to provide a model capable of bridging agency based and structural forms of power, a problem that would be tackled by the author only a decade later, in his Frameworks of Power (Clegg 1989). However what constitutes the main shortcoming in an otherwise stimulating and ideas-rich work is the writing style. The author seems at times too fond of showing erudition and depth of thinking which can be obfuscating and abstruse, reminiscent of Kant's prose. Still reading this work is worth the effort since it allows understanding of the evolution and transformation of the thought of one of the most acute organizational sociologists of our time and, with that, the transformation of our understanding of organizational power.

\section{Organization Class and Control}

Clegg and Dunkerley's (2013 [1980]) Organization Class and Control is an encyclopedic essay on the theory of organization which, despite its appearance, is not a mere review of the sociological literature on organizations as of 1980. What sets this work apart from apparently similar contemporary handbooks on the subject, such as Scott's (1981) 
Organizations, or Pfeffer's (1982) Organizations and organization theory, is it's forceful, critical and political message.

Arguing from a Marxist standpoint, the book has a strong leitmotif, advancing the idea that organizations are primarily means of control of the labor process, and that the issues of control, domination and power are central to understanding the organizational phenomenon. The authors do not present just another possible metaphor through which organizations can be understood, as in Morgan (2006): instead they make clear that the mainstream doctrine taught in business schools, presenting organization theory as a set of universal precepts on how to organize labor rationally, has becomes a hegemonic vehicle of ideological reproduction.

In Clegg and Dunkerley's narrative, organizations have a political (and often an oppressive) nature but are also essential constituents of a wider political economy, which they contribute to, structure and reproduce through their practices. Connecting the micro (organization of the firm) and the macro (organization of society) becomes central to the author's enquiry: they thereby problematize organizational boundaries, expanding them beyond those of the formal structure to include the wider labor process.

In order to critique, expand and innovate organizational discourse the authors embark on an extensive and insightful, if sometimes idiosyncratic, review of the ideas that have shaped organizational theorizing. Moving from the sociological precursors whose ideas were influenced by the emergence of modern forms of industrial organization (Comte, Saint-Simon, Spencer, and Durkheim), Clegg and Dunkerley contrast the Weberian idea of organization as a consequence of the process of global rationalization with Marxian analysis explaining organizational choices in relation to the rise of capitalist accumulation. In the last of the three initial historical chapters, the emergence of Taylor's scientific organization and formal administration theories are discussed and put in context but also contrasted not only with (as happens in most manuals) the Human Relations school but, more interestingly, with Gramsci's critique.

Each of the following three chapters focus on three directions in organization studies: identification, building on Weber, of ideal organizational types; the view of organizations 
as functional systems, and contingency theory with its set of empirical heuristics for measuring organizations (that Clegg and Dunkerley find wanting).

While all these approaches are critiqued for reifying organizations, presenting them as stable, material constructs, the next chapter presents a diametrically opposite theoretical perspective, represented by theories describing organizations phenomenologically, as structures of human action. Considering the emergent and disputed nature of organization leads the authors to reflect (in chapter 8) on the problem of organizational goals, and in particular on their ambiguity, vagueness and volatility. Contingency theory is again attacked in the two following chapters: first the idea that technology is a determinant of organization is rejected; it is instead proposed, following Braverman, that technological change is instrumental in minimizing worker skills in order to maximize managerial control. Also environmental determinism is panned, on account of the large potential for organizations (multinationals in particular) to influence directly the environments in which they operate.

The next chapter treats another topic that at the time was neglected in organization studies, gender inequality and the relationship between industrial and labor process. In the 12th chapter power in organizations is explicitly discussed (rather than hinted at as in the previous chapters), and used to connect organizations and the broader social context in which they are inscribed. Finally, in the last chapter, Clegg and Dunkerley propose a political economy of organizations, in the attempt to reform a discipline that has gone astray from its sociological and critical origins and been transformed into a technocratic, conservative and establishment-supporting canon.

Overall, this book appears a difficult "sell" to readers of the 2010s: treatment of the subject is too sophisticated to be adopted as an undergraduate or graduate manual and it is obviously not up to date with the last three decades of management research. Its span and extension appear too ponderous for a critical management essay and, above all, Marxist analysis seems out of fashion. For instance, the argument according to which technology does not directly shape organizations but its influence is filtered through a political process aiming at controlling labor seems to clash with the fact that the diffusion of information technologies has demanded an up-skilling (rather than de-skilling) of the 
workforce in contemporary advanced economies. The "stupid", "phlegmatic", ox-like laborer described by Taylor (1911, p. 59) has either turned into a cyborg or been recruited from the peasantry of East Asia into the swelling ranks of its proletariat.

Yet, if we consider the issue from a critical point of view we will realize that the argument that technology adoption has political precursors and consequences still stands. In fact, the very technologies promising to expand our senses, memory and intellect have a double edge, since they constitute powerful means of control and manipulation. Private information that users willingly surrender in social media are now routinely used by employers (Roth, Bobko, Van Iddekinge, and Thatcher 2013); users can be surreptitiously influenced in their choices and actions by the designers of the software and hardware they engage with and increased computational power becomes instrumental to the promotion of an agenda of "reduction of quality to quantity" (Marcuse, 1971, cited in Clegg and Dunkerley 2013 [1980], p. 136), promoting an agenda of constant acceleration (Czarniawska 2011). In this sense, the assurance of self-determination brought by technology is not less fraudulent than that of 'work humanization' criticized by Clegg and Dunkerley in the last chapter of the book.

One final point is worth making here: hasn't globalization, the casualization of work and the development of virtual organizations made the study of organizational structures obsolete and that of the political economy of organization a necessity? Many ideas presented in Organisation, class and control are still current and need to be read all over again to reflect critically on $21^{\text {st }}$ century organizations.

\section{The State, Class and the Recession}

The State, Class and the Recession, edited by Clegg, Dow and Boreham (2013 [1983]) was published during the height of economic crisis crippling western economies in the 1970s and 1980s. The edited volume consists of seven chapters selected from amongst the presentations delivered at an academic conference titled Organization, Economy and Society organized by the editors at an Australian University in July 1981.These chapters are valuable for their scholarship on the macro relationships between social forces, the state and economic performance. The core ideas of this book were further developed by 
the editors a couple of years later in another publication, which we shall review in more detail below.

\section{Class, Politics and the Economy}

Class, Politics and the Economy, authored by Clegg, Boreham and Dow (2013 [1986]) (the same team who edited The State, Class and the Recession), builds upon the ideas of the edited volume in a more integrated and sophisticated argument. Theorizing the mutual constitution of liberal capitalistic democracy by competing sociological, political, and economic forces, the thesis rests upon a framework constructed by incorporating Weberian insights into a revised Marxian theory. The insights generated are surprisingly relevant for analysis of the recent Global Economic Crisis of 2008 and of the emerging Asian economies, particularly the rise of a middle class in countries such as China, India and Indonesia.

Clegg, Boreham and Dow initiate their analysis by tracing the origin of Marx's ideas to Adam Smith and David Ricardo's division of society into a tripartite class structure and their concern with labor value. Simplifying Smith and Ricardo's theories to a dualistic class structure consisting of the bourgeoisie and the proletariat, Marx theorized an ongoing class struggle within democratic capitalistic society involving constructs of value, surplus value, and exploitation.

The authors highlight limitations in Marx's oversimplified dual class structure and draw upon Weber to distinguish between four social classes: the petty bourgeoisie (including small business owners), the new middle class (professional and middle level employees of large enterprises), the corporate ruling class (who own and control large enterprises) and the working class (who have neither ownership nor control over the means of production).

In Clegg, Boreham and Dow's analysis the role of the petty bourgeoisie is particularly important for capitalistic democracy. It is their advocacy of right-wing ideologies promoting laissez-faire economic individualism along with their opposition to government regulation, taxation, and social agendas that maintains the dominance of the minority corporate ruling class within the system. Class struggle is not automatic but rather must be organized by labor unions and carried into the arena of party politics. 
There the working and ruling classes compete for the votes of the new middle class, which maintains the balance of power in the liberal democratic capitalistic system.

Competitive market pressures and demands for larger surpluses, the authors explain, force the reduction of the cost of material goods by putting pressure on labor costs and costs of the means of production. Such unsustainable pressures mean that periodic economic crises are necessary for resetting property and labor values and perpetuating inequality in income distribution in the capitalist system. The authors compare macroeconomic outcomes from OEDC countries over time as they consider and dismiss Keynesian and monetary policy as solutions to this systemic problem due to the failure of these approaches in providing dependable full employment. Drawing on the same OEDC data, Clegg, Boreham and Dow bring attention to the Swedish experience, with minor reference to the political economy of (West) Germany, where the labor movement united in demanding alternative socio-economic arrangements involving a socialization of investment, which has a record of delivering steady economic performance along with reliable full employment. Acknowledging the unique socio-political history of these nations, the authors do not propose that the Swedish system can be applied in other contexts as a blanket policy but rather suggest the model as a starting point for reforming the capitalistic democratic political-economy.

A strong point of the work lies in the detailed and insightful comparative analysis of original sources such as Adam Smith, David Ricardo, Max Weber and Karl Marx, acting as a valuable reference for understanding the relationships and development of these scholar's ideas, which makes it a shame that this work has not received greater attention. A limitation is that the analysis naively gives too much weight to social, economic and political factors without considering other concerns such as the environment, gender and other forces that could also be fundamentally important.

\section{Further observations}

\section{The effects of academic practices on the production of knowledge}

The "juvenilia" of these six publications has more than historical or affective significance. They represent an empirical example of how dispositional and facilitative circuits of power affect the episodic creation of knowledge (and it's ironic to make these 
observations while examining Clegg's texts' theorizing on this very concept!). When we compare them with more recent works by the same hand on similar subjects we can observe not only an evolution of thought and the accumulation of knowledge but also the sociomaterial influence of factors external to the ideas but intrinsic to the practices of an academic: technology, institutional norms, discursive influences and embodied experiences.

Factors such as the availability of technology can drive a different approach to knowledge creation and dissemination. It is unusual to find more than 3-4 references per page (500 words); in comparison in recent papers by the same author there are typically more than 20 references for each 500 words. This suggests a change in practice driven by the availability of a set of technologies (search engines, direct access to electronic versions of sources via the web, citation software etc.) that makes finding suitable or relevant references much easier than in the past.

For instance, these works were originally handwritten and only subsequently typewritten, a long and laborious process of producing text through multiple iterations that invites reflection and reduces the temptation of "cutting and pasting". Information was only accessible through visits to libraries and therefore the physical location of the authors had an influence on the ideas to which they were exposed and the material they could cite.

As a consequence, in the 1970s-80s Stewart Clegg invested his time in reading a limited number of sources in greater depth, engaging deeply and reflectively with their content. The $21^{\text {st }}$ century Stewart Clegg is forced to skim thousands of articles, sifting through myriads of pieces of knowledge as a processor engulfs enormous quantities of ore to retain a few diamonds. His experience and craftsmanship, along with his rich network of relationships and memory-bank of academic references make for quite a comparison with his younger self.

The emergence of an academic "publishing game" (e.g. journals competing for ranking requiring the inclusion of a sizable number of citations to articles published in the same journals) which can make or break and academic career (Starbuck 2005), together with the McDonaldisation of academic knowledge (Parker and Jary 1995) driven by the 
growing importance of metrics and the dominant role played by publications in academic career advancements, has also produced new institutional norms perpetuated through the indoctrination practices of aspirant academics. It is noteworthy that at the time of writing and editing these six books Clegg had authored very few journal articles. It was only in the 1990s after he was explicitly appointed to frame a research culture at UTS that he started to focus on journal articles as well as books. Clegg's shift in focus towards writing articles was developed in parallel with changes in the audit culture of universities and a serious attempt on his part to get research grants. In his early career as a sociologist and in a School of Humanities, books were a 'normal' product; in management they were far less so. A little adjustment needed to be made, new games to be learnt. Even in this 'soft' science field, where knowledge is apparently developed without the aid of tangible research tools and laboratory equipment, the medium of knowledge transfer (book versus paper; a typewriter versus a word processor; a discussion while sharing a tea versus a wiki based collaboration) seems to produce different kinds of inscriptions. The interpretive work of the researcher (Latour and Woolgar 1979), is thereby mediated by the means contributing to a translation of the product of knowledge.

With advances in technology and changing conventions, values and contexts, it is unavoidable that approaches to literature review, analysis and knowledge generation will be different: In this review we observe that they have become broader at the expense of in-depth engagement with ideas. To use Cleggian analytics (Clegg 1989), transformations in the dispositional circuit of power (institutional demands to hyper-cite and produce research-based journal publications), combined with alterations in the facilitative circuit (the information technology revolution at the turn of the century), has brought about a different intellectual practice in the episodic circuit (individual practices of academic knowledge production). Other material aspects such as the influence of academic colleagues and production time along with the number of required iterations will also play a role in changing outcomes. However, there is not enough evidence (or space) to ascertain the impact of these factors in this review.

\section{Theories/Ideas lost?}


Ideas and dominant discourses also play a role in shaping knowledge production. The field of critical management and the use of sociologically inspired "soft", interpretive and qualitative methods, was a pioneering field in the 1970s and early 1980s. Now the same ideas have become almost mainstream and find a comfortable home in a large number of high quality, qualitative leaning, organizational and management journals. It is much easier now to make a successful academic career embracing this anti-positivistic and critical stance on management. Critical management studies have become a legitimate alternative form of establishment, rather than the marginal, almost subversive space occupied by the young Clegg.

These reflections raise another important issue relating to the importance of going back to original sources and acknowledging their intrinsic intellectual and knowledge value. If knowledge production is influenced by contingent socio-material factors, then a different setting will produce qualitatively different knowledge. This should debunk the positivist myth of knowledge as continuous, progressive accumulation, along with the often tacitly accepted tenet that later works will include what is still worth knowing from earlier works. Such an assumption might be (quite) accurate in the hard sciences or in technology but it is certainly unwarranted in the social sciences.

These reflections imply that any form of knowledge, including scientific learning, should be treated as a relational product, emergent from the interaction among a set of material, ideal and institutional elements. Such a perspective does not necessarily require embracing a radical post-modern ontology. It should rather be seen as contributing to a fully developed critical view, where readers become aware of the influence of different discursive forces shaping the "conversation" between authors and their readers.

\section{Conclusion}

If we acknowledge that the social influences of power and discourse define knowledge; if we recognize the impact, as in the abovementioned examples, of embodied and situated practices on the production and dissemination of knowledge in social sciences, then we must recognize how the reflections produced in a different era, under different cultural and economic influences, as well as different material opportunities and constraints, can be qualitatively different and valuable. Reading these texts provides more than mere 
insight into the formation of an influential mind and an academic persona, it also facilitates - through critical engagement with these texts - the discovery of another powerful voice whose ideas can be as original and innovative now as Clegg's were 40 years ago, since the reader is "not to be thought a passive 'receiver' of news, but [...] an active collaborator" (Clegg 2013 [1975], p. 157). By short-circuiting half a century thanks to these new editions, we can create a novel, fecund occasion for debate and ideageneration.

\section{References}

Bachrach, P., \& Baratz, M. S. (1962). Two faces of power. American Political Science Review, 56(4), 947-952.

Clegg, S. (2013 [1979]). The theory of power and organization. Oxon: Routledge Revivals.

Clegg, S. R. (1989). Frameworks of power. London: Sage.

Clegg, S. R. (2005). Vita contemplativa: A life in part. Organization Studies, 26(2), 291-309.

Clegg, S. R. (2013 [1975]). Power, rule and domination. Oxon: Routledge.

Clegg, S. R., Boreham, P., \& Dow, G. (2013 [1986]). Class, politics and the economy. Oxon: Routledge.

Clegg, S. R., Cunha, M. P., \& Rego, A. (2012a). The evil of utopia. In C. L. Jurkiewicz (Ed.), Foundations of Organizational Evil (pp. 225-244). Thousand Oaks, CA: Sage.

Clegg, S. R., Cunha, M. P., \& Rego, A. (2012b). The Theory and practice of utopia in a total institution: The pineapple panopticon. Organization Studies, 33(12), 1735-1757.

Clegg, S. R., Dow, G., \& Boreham, P. (2013 [1983]). The state, class and the recession. Oxon: Routledge.

Clegg, S. R., \& Dunkerley, D. (2013 [1977]). Critical issues in organizations. Oxon: Routledge.

Clegg, S. R., \& Dunkerley, D. (2013 [1980]). Organization, class and control. Oxon: Routledge.

Czarniawska, B. (2011). Cyberfactories: How news agencies produce news: Edward Elgar Publishing.

Dahl, R. A. (1957). The concept of power. Behavioral science, 2(3), 201-215.

Foucault, M. (1977). Discipline and punish: The birth of the prison (A. Sheridan, Trans.). New York: Pantheon.

Fournier, V., \& Grey, C. (2000). At the critical moment: conditions and prospects for critical management studies. Human Relations, 53(1), 7.

Garfinkel, H. (1967). Studies in ethnomethodology. Cambridge: Polity Press.

Giddens, A. (1976). New rules of sociological method: A positive critique of interpretative sociologies. London: Hutchinson. 
Gramsci, A. (1971). Selections from the prison notebooks. London: Lawrence \& Wishart.

Latour, B., \& Woolgar, S. (1979). Laboratory life: The social construction of scientific facts. Princeton: Princeton University Press.

Lukes, S. (1974). Power: A radical view. Macmillan, 218, 297-314.

Morgan, G. (2006). Images of organization. Thousand Oaks, CA: Sage.

Parker, M., \& Jary, D. (1995). The McUniversity: Organization, management and academic subjectivity. Organization, 2(2), 319-338.

Pfeffer, J. (1982). Organizations and organization theory. Boston: Pitman.

Roth, P. L., Bobko, P., Van Iddekinge, C. H., \& Thatcher, J. B. (2013). Social media in employee-selection-related decisions: A research agenda for uncharted territory. Journal of Management, 0149206313503018.

Scott, W. R. (1981). Organizations: Rational, natural, and open systems. Englewood Cliffs, NJ: Prentice Hall.

Simon, H. (1952). A comparison of organisation theories. The Review of Economic Studies, 20(1), 40-48.

Simpson, A. V., Clegg, S., \& Freeder, D. (2013). Power, compassion and organization. Journal of Polical Power, 6(3), 385-404.

Starbuck, W. H. (2005). How much better are the most-prestigious journals? The statistics of academic publication. Organization Science, 16(2), 180-200.

Taylor, F. W. (1911). The principles of scientific management. New York, NY: Harper Bros. 